\title{
Judge backs technique
}

\section{Washington}

IN the New York double-murder trial that has become a test case for the forensic use of DNA 'genetic fingerprinting', Justice Gerald Sheindlin last week ruled that the identification techniques are generally reliable and admissible as evidence. Genetic fingerprinting thus emerges from what Sheindlin described as its "most comprehensive and extensive legal examination ... in the United States" with backing for its use both to demonstrate exclusions (that two samples are not the same) and inclusions (the more difficult test that two samples are identical).

The decision comes with the recommendations that, in future trials, "a pretrial hearing should be conducted to determine if the testing laboratory substantially performed the scientificially accepted tests and techniques, yielding sufficiently reliable tests to be admissible". In the particular case under examination, Sheindlin ruled that the testing laboratory had, on one inclusion test, "failed in several major respects to use the generally accepted scientific techniques and experiments for obtaining reliable results"

Peter Neufeld, one of the defence lawyers in the case, believes that despite the new recommendations, the judge "did not go far enough" in his criticisms. When the judge decided the evidence was in a general sense reliable, Neufeld says, he was "responding to the hopefulness of our expert witnesses rather than their assessment that these standards and procedures were currently in place". But Neufeld adds that, as the case represents "the very first time that any judge has excluded DNA evidence of a match, on the grounds that the tests were not done in a sufficiently reliable fashion, it has tremendous impact on testing laboratories nationwide".

The DNA identification evidence is of vital significance in the trial of Joseph Castro, a 38-year-old resident of the Bronx, accused of stabbing to death a 20 -year-old pregnant woman and her two-year-old daughter. A wrist-watch worn by Castro at the time of his arrest appeared to carry a bloodstain. Castro claimed that the blood was his own. DNA identification tests were performed by the forensic and paternity testing company, Lifecodes Corporation of Valhalla, New York, and were claimed to show that the blood came from the murdered woman rather than Castro.

A pre-trial hearing examined whether the scientific procedures involved met the 'Fyre' test of being "generally accepted as reliable" by the scientific community. The hearing quickly turned into an intense examination of forensic DNA tests in general and of the methods used by Lifecodes Corporation in this particular case.
Approximately 5,000 pages of evidence were amassed over the 12 weeks and a series of distinguished scientists testified for the prosecution and for the defence. The hearing took an unusual twist when defence and prosecution witnesses got together and agreed that some of the evidence was not scientifically reliable.

Although there was speculation that the judge might rule DNA testing inadmissible, the final decision accepts its general validity. In the particular case under consideration, the ruling accepted that Lifecodes Corporation showed that the blood on the watch did not come from the defendant. But the judge ruled inadmissible the company's evidence that the blood matched that of the victim.

Despite the implied criticism of their procedures, Lifecode's senior vicepresident John Winkler said he was "delighted that the judge recognized that using DNA for forensic testing is valid". Winkler also accepted the judge's view that "a preliminary, critical examination of the actual testing procedures performed in a particular case" should be conducted before the start of a trial employing DNA identification tests. The judge notes that the test results are bound to have a "powerful impact" on a jury and makes twelve recommendations of what should be presented at a pre-trial hearing.

Winkler says that Lifecodes "agrees with all of the judge's recommendations". Among them are details of the method used to declare a match or nonmatch between samples, the methods used to calculate the allele frequency in the relevant population and tests performed to determine the origin of contaminants. Evidence on all these points was strongly debated during the Castro hearing (see Nature 339, 501; 15 June 1989).

Comprehensive guidelines for the forensic use of DNA fingerprinting are still lacking, and the National Academy of Sciences is still hoping to find funds for a detailed study. Meanwhile the Federal Bureau of Investigation (FBI), whose laboratories see themselves as leaders in the forensic DNA analysis field, has brought together molecular biologists, testing-laboratory representatives and its own experts to exchange viewpoints.

Neufeld says, however, says that state and federal legislation is necessary, Included should be accreditation of laboratories, certification and licensing of personnel, quality control standards, and proficiency studies.

"It's absurd", says Neufeld "to think that you do not have all that in a testing procedure which determines who lives and who dies, or at a minimum who goes away to prison for 30 years".

Alun Anderson
Japanese scientists stay clear of China for time being

\section{Kyoto \& Tokyo}

JAPAN's Ministry of Education, Science and Culture (MESC) has been quietly cutting off the flow of Japanese scientists to China in the wake of the Tiananmen Square killings. Although the ministry has made no official announcement, information on travel grant applications released earlier this month show that visits to China are no longer winning support.

Immediately after the imposition of martial law in China, Japanese government officials and academics involved in academic exchange with China said only that they were "watching the situation" and had no immediate plans to suspend their exchange programmes.

But, it has now emerged that on 6 June, MESC sent a directive to all national universities and research institutes advising against visits to China. The directive is not legally binding but has had the effect of bringing visits by Japanese academics to China to a virtual halt.

A group of mineralogists at Kyoto University led by Professor Shohei Banno had been expecting to receive a grant for a long-planned collaborative project with the the Chinese Academy of Sciences to look for unusual minerals in eastern China. But the grant was not among those announced this month. Private funds are available for the trip but because permission for leave of absence must be obtained from the university, the trip cannot go ahead.

Figures provided last week by the Japan Society for the Promotion of Science (JSPS), a semi-governmental organization funded by MESC, also show that the flow of scientists to China has fallen to a trickle. Normally about 30 to 50 Japanese scientists visit China each year under JSPS programmes. But since 4 June only one scientist has been despatched and many have postponed their trips, according to a JSPS spokesman.

The ministry is particularly anxious to avoid having Japanese scientists in Beijing, where martial law is still in force, according to Rinjin Ogasawara, a MESC spokesman on China. Grants that have already been awarded for trips to Beijing can be used for journeys elsewhere, including other countries, or they can be returned to the ministry, as some have been, Ogasawara says.

In the future, however, it seems likely that the flow of Japanese scientists to China (excluding Beijing) will resume. The foreign ministry announced last week that it is withdrawing its advice against Japanese nationals travelling to China, except Beijing, and economic assistance will also be resumed.

Simon Wallis \& David Swinbanks 